\title{
Short Communication \\ Aspirin use and cancers of the upper aerodigestive tract
}

\author{
C Bosetti*,', R Talamini ${ }^{2}$, S Franceschi ${ }^{3}$, E Negri' $^{1}$ W Garavello ${ }^{4}$ and C La Vecchia ${ }^{1,5}$ \\ 'Istituto di Ricerche Farmacologiche 'Mario Negri', Via Eritrea 62, 20157 Milan, Italy; ${ }^{2}$ Servizio di Epidemiologia, Centro di Riferimento Oncologico, Via \\ Pedemontana Occ.le, 33081 Aviano (Pordenone), Italy; International Agency for Research on Cancer, 150 Cours Albert Thomas, F-69372 Lyon Cédex \\ 08, France; ${ }^{4}$ Ospedale 'San Gerardo', Università di Milano Bicocca, Via Donizetti 106, 20052 Monza, Italy; Istituto di Statistica Medica e Biometria, \\ Università degli Studi di Milano, Via Venezian I, 20133 Milan, Italy
}

The role of aspirin on the risk of cancers of the upper aerodigestive tract was investigated in the combined data of three Italian casecontrol studies, including 965 cases and 1779 hospital controls. The odds ratio was 0.33 for users of $\geqslant 5$ years, and $0.5 \mathrm{I}$ for $\geqslant 5$ years since first use.

British Journal of Cancer (2003) 88, 672-674. doi: I0.1038/sj.bjc.6600820 www.bjcancer.com

(c) 2003 Cancer Research UK

Keywords: upper aerodigestive tract cancer; aspirin; case-control study; risk factor

Data on the role of aspirin on the risk of cancers of the upper aerodigestive tract are scanty, and mainly related to cancer of the oesophagus. In two rheumatoid arthritis cohorts from Finland (Isomäki et al, 1978) and Sweden (Gridley et al, 1993), no significant association between aspirin use and oesophageal cancer risk was observed (relative risk $(R R)=0.94$ and 1.3 , respectively). In a large prospective study from the American Cancer Society, a significantly reduced risk of oesophageal cancer $(R R=0.59)$ was reported in subjects who used aspirin $\geqslant 16$ times per month for at least 1 year, and the risk reduction was stronger among users for $\geqslant 10$ years $(\mathrm{RR}=0.54)$ (Thun et al, 1993). In the same study, a nonsignificant increased risk was observed for oral and pharyngeal cancer. In the cohort of the National Health and Nutrition Examination Survey, aspirin use was associated with a $90 \%$ decreased risk of developing oesophageal cancer, although the estimate was based on 15 cases only (Funkhouser and Sharp, 1995). A US population-based casecontrol study, including 221 squamous-cell oesophageal cancer and 293 adenocarcinoma cases, found a significant lower risk for current aspirin users (odds ratio $(\mathrm{OR})=0.49$ for squamous-cell and 0.37 for adenocarcinoma) (Farrow et al, 1998). In a British case-control study conducted on 159 women with squamous-cell oesophageal cancer, 10 cases vs 19 controls reported taking aspirin daily for at least 1 month (crude OR $\geqslant 0.50$ ) (Sharp et al, 2001). In a casecontrol study from Greece with 43 squamous-cell cancers and 56 adenocarcinomas of the oesophagus, the OR was nonsignificantly reduced for ever aspirin use (Garidou et al, 1996).

The potential role of aspirin use on cancers of the upper aerodigestive tract was further investigated using data from three case-control studies conducted in Italy.

\section{PATIENTS AND METHODS}

Three hospital-based case-control studies of cancer on the upper aerodigestive tract were conducted in Italy between 1992 and 2000 to examine alcohol, tobacco, diet, family history and other

*Correspondence: Dr C Bosetti; E-mail: bosetti@marionegri.it

Received 14 October 2002; revised 15 December 2002; accepted I8 December 2002 environmental factors, covering a total of 1362 cases and 3038 hospital controls (Franceschi et al, 1999; Bosetti et al, 2000; Talamini et al, 2002).

Controls were from the same hospitals as cases, admitted for a wide spectrum of acute, non-neoplastic conditions, not related to smoking, alcohol consumption or long-term modifications of diet; they were frequency-matched with cases by 5 -year age groups, sex and study centre. To compensate for the rarity of laryngeal cancer in women, a control-to-case ratio of about 5 was chosen for women, as opposed to 2 for men. On average, $5 \%$ of cases and controls approached during their hospital stay refused to be interviewed (Franceschi et al, 1999; Bosetti et al, 2000; Talamini et al, 2002).

The interview-administered questionnaire included information on sociodemographic characteristics, anthropometric measures, lifestyle habits, including tobacco smoking and alcohol drinking, a validated food frequency section and personal and family medical history. The information on aspirin intake included indication, age at first use, frequency and duration of use. Regular use was defined as use for at least once a week for more than 6 months. To facilitate recall of use, a comprehensive list of major aspirin-containing preparations in Italy was supplied.

A total of 965 cases ( 850 men, 115 women) of the upper aerodigestive tract cancer (393 oral and pharyngeal, 225 oesophageal and 347 laryngeal cancer) and 1779 (1450 men, 329 women) controls with information on aspirin use were included in the present analysis.

ORs and the corresponding 95\% confidence intervals (CI) were estimated using unconditional multiple logistic regression models (Breslow and Day, 1980), including terms for age, sex, study centre, years of education $(<7,7-11, \geqslant 12)$, alcohol $(<14,14-27,28-55$, $\geqslant 56$ drinks per week, plus a dummy variable for ex-drinkers) and tobacco consumption (never, ex-smoker, current smoker of $<15$, $15-24, \geqslant 25$ cigarettes per day).

\section{RESULTS}

Table 1 gives the distribution of 965 upper aerodigestive cancer cases and 1779 controls according to selected measures of aspirin 
Table I Distribution of 965 cases of cancers of the upper aerodigestive tract and 1779 controls, and the corresponding ORs with $95 \% \mathrm{Cl}$, according to various measures of aspirin use. Italy, 1992-2000

\begin{tabular}{|c|c|c|c|}
\hline & Cases & Controls & OR $(95 \% \mathrm{Cl})^{a}$ \\
\hline Nonusers & 928 & 1692 & $1^{\mathrm{b}}$ \\
\hline Regular users & 37 & 87 & $0.89(0.56-1.43)$ \\
\hline \multicolumn{4}{|c|}{ Duration of use $e^{c}$ (years) } \\
\hline$<5$ & 29 & 45 & $1.46(0.82-2.57)$ \\
\hline$\geqslant 5$ & 7 & 40 & $0.33(0.13-0.82)$ \\
\hline \multicolumn{4}{|c|}{ Time since first use (years) } \\
\hline$<5$ & 23 & 32 & $1.68(0.87-3.27)$ \\
\hline$\geqslant 5$ & 14 & 55 & $0.51(0.26-0.99)$ \\
\hline
\end{tabular}

${ }^{a}$ Estimates from unconditional logistic regression adjusted for sex, age, centre, education, tobacco smoking and alcohol drinking. ${ }^{\text {b}}$ Reference category. ${ }^{\mathrm{C}}$ The sum does not add up to the total because of some missing values.

use. A total of $37(3.8 \%)$ cases vs $87(4.9 \%)$ controls reported regular aspirin use. Average frequency of use was 5.7 times per week among cases and 5.6 among controls; 32 cases and 78 controls took aspirin $\geqslant 3$ times per week, 27 cases and 57 controls every day. Indication of use was analgesia for 10 cases and 38 controls, whereas 27 cases and 49 controls took aspirin for cardiovascular prevention. The multivariate OR for regular use was 0.89 (95\% CI $0.56-1.43)$. The OR decreased to 0.33 (95\% CI $0.13-$ 0.82 ) for users of $\geqslant 5$ years, and was 0.51 (95\% CI $0.26-0.99)$ for $\geqslant 5$ years since first use.

A reduced risk with longer duration of aspirin use was observed for all sites considered: the ORs for $\geqslant 5$ years of use were 0.39 for oral and pharyngeal, 0.80 oesophageal and 0.09 laryngeal cancer. Similarly, the ORs for $\geqslant 5$ years since first use were $0.26,0.66$ and 0.55 for the three cancer sites, respectively.

\section{DISCUSSION}

This study suggests that aspirin may have a beneficial effect on cancers of the upper aerodigestive tract. Although there is evidence of a possible protective effect of aspirin on oesophageal cancer (Bosetti et al, 2002), only scattered epidemiological data exist on its role on cancer of the oral cavity or larynx (Thun et al, 1993).

A significant reduced risk has been observed particularly for long-term use and in relation to a longer time since first use. These time-risk relations are similar to those described for colorectal

\section{REFERENCES}

Bosetti C, Gallus S, La Vecchia C (2002) Aspirin and cancer risk: an update to 2001. Eur J Cancer Prev 11: 535-542

Bosetti C, La Vecchia C, Talamini R, Simonato L, Zambon P, Negri E, Trichopoulos D, Lagiou P, Bardini R, Franceschi S (2000) Food groups and risk of squamous cell esophageal cancer in Northern Italy. Int $J$ Cancer 87: 289-294

Breslow NE, Day NE (1980) Statistical Methods in Cancer Research. Vol. I, The Analysis of Case-Control Studies. IARC Sci Publs no. 32. Lyon: International Agency for Research on Cancer

Chan G, Boyle JO, Yang EK, Zhang F, Sacks PG, Shah JP, Edelstein D, Soslow RA, Koki AT, Woerner BM, Masferrer JL, Dannenberg AJ (1999) Cyclooxygenase-2 expression is up-regulated in squamous cell carcinoma of the head and neck. Cancer Res 59: 991 994

Farrow DC, Vaughan TL, Hansten PD, Stanford JL, Risch HA, Gammon MD, Chow W-H, Dubrow R, Ahsan H, Mayne ST, Schoenberg JB, West AB, Rotterdam H, Fraumeni Jr JF, Blot WJ (1998) Use of aspirin and cancer (Giovannucci et al, 1995, IARC, 1997; Thun et al, 2002), and therefore give plausibility to a causal association.

With reference to possible biological mechanisms, aspirin, as well as other nonsteroidal anti-inflammatory drugs (NSAID), acts on the arachidonic acid metabolism, blocking the synthesis of thromboxane, prostacyclin and prostaglandins, which in turn can influence cell proliferation, and hence cancer growth (Marnett, 1992; Marcus, 1995). A specific target of the protection against colorectal and other cancers by aspirin and other NSAID is the inhibition of cyclooxygenase-2, which is important for apoptosis, and therefore for control of the mechanisms of carcinogenesis (Featherstone, 1997; Hong and Sporn, 1997; Taketo, 1998a, b; Smith et al, 2000). The same mechanisms may be responsible for the favourable action of aspirin on oesophageal cancer and other cancers of the upper aerodigestive tract (Morgan and Vainio, 1998; Chan et al, 1999; Zimmermann et al, 1999; Li et al, 2000).

Limitations of our study should be considered that might have introduced a spurious association between aspirin use and the reduced risk of upper aerodigestive tract cancers. It is possible in fact that aspirin use has been affected by early symptoms of the conditions under study. The evidence of an association with longer use is, however, reassuring against this bias. Further, some of the diagnostic categories of the controls may be associated with increased aspirin use. However, the results were similar when cases were compared with each of the major diagnostic categories of controls, thus giving reassurance against potential selection biases. Another limitation of this study is that, although based on a large number of cases, it includes a relatively low number of regular aspirin users, reflecting the pattern of regular aspirin use in Italy. Among the strengths of the study are the similar catchment areas for cases and controls, the almost complete participation rate and the choice of hospitals controls, who are preferable to population ones with reference to reliability and validity of information on drug use, since cases and controls are similarly sensitised towards various aspects of their medical history (Kelly et al, 1990). Moreover, the risk estimates were adjusted for major risk factors for cancers of the upper aerodigestive cancer, that is, tobacco smoking and alcohol drinking, suggesting therefore that the inverse relation between long-term aspirin use and cancers of the upper aerodigestive tract is real.

\section{ACKNOWLEDGEMENTS}

This work was conducted with the contribution of the Italian Association for Cancer Research, and the Italian League Against Cancer. We thank Mrs MP Bonifacino for her editorial assistance. other nonsteroidal anti-inflammatory drugs and risk of oesophageal and gastric cancer. Cancer Epidemiol Biomarkers Prev 7: 97-102

Featherstone C (1997) Aspirin for bowel cancer: an old friend finds a new role. Lancet 350: 418

Franceschi S, Levi F, Conti E, Talamini R, Negri E, Dal Maso L, Boyle P, Decarli A, La Vecchia C (1999) Energy intake and dietary pattern in cancer of the oral cavity and pharynx. Cancer Causes Control 10: 439444

Funkhouser EM, Sharp GB (1995) Aspirin and reduced risk of oesophageal carcinoma. Cancer 76: 1116-1119

Garidou A, Tzonou A, Lipworth L, Signorello LB, Kalapothaki V, Trichopoulos D (1996) Life-style factors and medical conditions in relation to esophageal cancer by histologic type in a low-risk population. Int J Cancer 68: 295-299

Giovannucci E, Egan KM, Hunter DJ, Stampfer MJ, Colditz GA, Willett WC, Speizer FE (1995) Aspirin and the risk of colorectal cancer in women. $N$ Engl J Med 333: 609-614 
Gridley G, McLaughlin JK, Ekbom A, Klareskog L, Adami H-O, Hacker DG, Hoover R, Fraumeni Jr JF (1993) Incidence of cancer among patients with rheumatoid arthritis. J Natl Cancer Inst 85: 307 - 311

Hong WK, Sporn MB (1997) Recent advances in chemoprevention of cancer. Science 278: $1073-1077$

IARC Handbooks of Cancer Prevention (1997) Non-Steroidal AntiInflammatory Drugs, Vol. 1. Lyon: International Agency for Research on Cancer

Isomäki HA, Hakulinen T, Joutsenlahti U (1978) Excess of lymphomas, leukemia, and myeloma in patients with rheumatoid arthritis. J Chron Dis 31: 691-696

Kelly JP, Rosenberg L, Kaufman DW, Shapiro S (1990) Reliability of personal interview data in a hospital-based case-control study. Am J Epidemiol 131: 79-90

Li M, Lotan R, Levin B, Tahara E, Lippman SM, Xu XC (2000) Aspirin induction of apoptosis in oesophageal cancer: a potential for chemopre vention. Cancer Epidemiol Biomarkers Prev 9: 545-549

Marcus AJ (1995) Aspirin as prophylaxis against colorectal cancer. N Engl J Med 333: $656-658$

Marnett LJ (1992) Aspirin and the potential role of prostaglandins in colon cancer. Cancer Res 52: 5575- 5589

Morgan G, Vainio H (1998) Barrett's oesophagus, oesophageal cancer and colon cancer: an explanation of the association and cancer chemopreventive potential of non-steroidal anti-inflammatory drugs. Eur J Cancer Prev 7: $195-199$
Sharp L, Chilvers CED, Cheng KK, McKinney PA, Logan RFA, CookMozaffari P, Ahmed A, Day NE (2001) Risk factors for squamous cell carcinoma of the oesophagus in women: a case-control study. $\mathrm{Br} J$ Cancer 85: $1667-1670$

Smith ML, Hawcroft G, Hull MA (2000) The effect of non-steroida anti-inflammatory drugs on human colorectal cancer cells: evidence of different mechanisms of action. Eur J Cancer 36: 664-674

Taketo MM (1998a) Cyclooxygenase-2 inhibitors in tumorigenesis (Part I). J Natl Cancer Inst 90: 1529-1536

Taketo MM (1998b) Cyclooxygenase-2 inhibitors in tumorigenesis (Part II). J Natl Cancer Inst 90: 1609-1620

Talamini R, Bosetti C, La Vecchia C, Dal Maso L, Levi F, Bidoli E, Negri E, Pasche C, Vaccarella S, Barzan L, Franceschi S (2002) Combined effect of tobacco and alcohol on laryngeal cancer risk: a case-control study. Cancer Causes Control 13: $951-964$

Thun MJ, Henley SJ, Patrono C (2002) Nonsteroidal anti-inflammatory drugs as anticancer agents: mechanistic, pharmacologic, and clinical issues. J Natl Cancer Inst 94: 252-266

Thun MJ, Namboodiri MM, Calle EE, Flanders WD, Heath Jr CW (1993) Aspirin use and risk of fatal cancer. Cancer Res 53: 1322 1327

Zimmermann KC, Sarbia M, Weber AA, Borchard F, Gabbert HE, Schror K (1999) Cyclooxygenase-2 expression in human esophageal carcinoma. Cancer Res 159: 198-204 